FIU Law Review

Spring 2013

\title{
Mind Which Gap? The Selective Concern Over Statistical Sex Disparities
}

Kingsley .. Browne

Wayne State University Law School, Detroit

Follow this and additional works at: https://ecollections.law.fiu.edu/lawreview

Part of the Other Law Commons

Online ISSN: 2643-7759

\section{Recommended Citation}

Kingsley .. Browne, Mind Which Gap? The Selective Concern Over Statistical Sex Disparities, 8 FIU L. Rev. 271 (2013).

DOI: https://dx.doi.org/10.25148/lawrev.8.2.5

This Article is brought to you for free and open access by eCollections. It has been accepted for inclusion in FIU Law Review by an authorized editor of eCollections. For more information, please contact lisdavis@fiu.edu. 


\title{
Mind Which Gap? \\ The Selective Concern Over Statistical Sex Disparities
}

\author{
Kingsley R. Browne*
}

\section{INTRODUCTION}

The theme of this conference is that there are "gaps" that require attention. According to the conference materials, "vast disparities in compensation, power, and titles persist between the sexes today." The question raised in this symposium is "how can this gap be explained and rectified?" This question assumes that the "gap" should be rectified regardless of its cause.

Although the workplace is the primary focus of this conference, I would like to put the workplace into a broader context and look at other "gaps" that exist, as well. The sexes differ in a number of respects that do not favor men. Men die at a younger age than women; they are more likely to be victimized by crime; they are more likely to be imprisoned (and for longer times); they are, according to many, disfavored in the domestic-relations arena; and they do less well by many measures in the educational system. Far fewer people tend to be concerned about these "gaps," or even to characterize them as such, presumably because they are hard to characterize as victimization of women.

\section{STATISTICAL GAPS}

\section{A. Health and Longevity}

The sexes differ substantially in health and health care. First, of course, is the well-known difference in life expectancy. In the United States in 2011, life expectancy at birth was 81.1 years for females and 76.3 years for males, a greater difference in life expectancy than exists between blacks and whites. ${ }^{1}$ Boys from infancy to 19 years are twice

\footnotetext{
* Wayne State University Law School, Detroit, MI 48202, kingsley.browne@wayne.edu.

1 Donna L. Hoyert \& Jiaquan Xu, Nat'L Vital Statistics Reports, Deaths: PRELIMINARY DATA FOR 2011 1, 3 (2012), http://www.cdc.gov/nchs/data/nvsr/nvsr61/
} 
as likely to die of accidental injury, and this is true in each age cohort and race, and from each type of injury. ${ }^{2}$ Men also commit suicide at four times the rate of women.

Despite the fact that males lag behind on a number of healthrelated measures, it is "women's health" that gets most of the public attention and a disproportionate share of resources. ${ }^{4}$ The United States Department of Health and Human Services has an "Office on Women's Health" (in addition to an "Office of Minority Health" and "Office of Adolescent Health"), but no "Office on Men's Health." Indeed, a Google search of the HHS website yielded 1,980 hits for "women's health," but only 50 hits for "men's health." A Medline search using the keyword phrase "women's health" returned 36,503 articles, while a search using the phrase "men's health" turned up only 2,994 . Women also consume substantially greater health-care resources than men, ${ }^{8}$ a difference that is only partially a consequence of the sex difference in life expectancy.

\section{B. Crime and the Criminal Justice System}

Although we hear much about "violence against women," and we even have a well-known law called the Violence Against Women Act, ${ }^{10}$

nvsr61_06.pdf. The life expectancy for whites and blacks at birth was 79.0 and 75.3 years, respectively. $I d$.

2 Nagesh N. Borse et Al., Ctrs. For Disease Control and Prevention, CDC CHILdHOOd INJURY REPORT: PATTERNS OF UNINTENTIONAL INJURIES AMONG 0-19 YeAR OLDS IN THE UNITED STATES, $2000-2006$ 3, 26, 34-35 (2008), http://www.cdc.gov/ safechild/images/CDC-childhoodinjury.pdf.

3 Centers for Disease Control and Prevention, Suicide: Facts at a Glance 2012, http://www.cdc.gov/ViolencePrevention/pdf/Suicide_DataSheet-a.pdf.

4 This is not a new phenomenon. See Andrew G. Kadar, The Sex-Bias Myth in Medicine, AtLAnTIC MonThly, Aug. 1994, at 66 (noting that "[t]hough it is commonly believed that American health-care delivery and research benefit men at the expense of women, the truth appears to be exactly the opposite").

5 OFF. ON WOMEN's HEALTH, http://www.womenshealth.gov/about-us (last visited Apr. 19, 2013).

OFF. MiNORITY HEALTH, http://minorityhealth.hhs.gov (last visited Apr. 19, 2013).

OFF. AdOLESCENT HEALTH, http://www.hhs.gov/ash/oah (last visited Apr. 19, 2013).

8 Berhanu Alemayehu \& Kenneth E. Warner, The Lifetime Distribution of Health Care Costs, 39 HEALTH SERVICES RES. 627, 634 (2004) (finding that total lifetime health-care expenditure of women is $34 \%$ greater than that of men); Evelyn L. Forget et al., Variations in Lifetime Healthcare Costs Across a Population, 4 HEALTHCARE POL'Y e148, e158 (2008) (women incur 40\% more healthcare costs than men over their lifetime). See generally Roni Rabin, Health Spending: Health Disparities Persist for Men, and Doctors Ask Why, N.Y.TIMES, Nov. 14, 2006, at F1.

9 Alemayehu \& Warner, supra note 8 , at 635 (finding that $40 \%$ of the sex disparity in health-care expenditures was a consequence of women's longer life expectancy).

10 Violence Against Women Act, Pub. L. No. 103-322, 108 Stat. 1796 (codified as amended in scattered sections of 18 U.S.C. and 42 U.S.C.). It is true that the law is written in sex-neutral terms, but there is little doubt from either its title or the circumstances surrounding its passage 
men constitute the majority of victims of violent crime, both serious and non-serious. ${ }^{11}$ More than three-fourths of all murder victims, and about six out of seven of those between the ages of 17 and 29, are male. ${ }^{12}$ Despite occasional claims to the contrary, ${ }^{13}$ people have much more negative views about violence against women than violence against men.

The only category of violent crime from which women suffer more than men is sexual assault, although the extent of the disparity is not entirely clear because men are less likely to report sexual assaults than women. ${ }^{15}$ Everyone recognizes, of course, that sexual assault of a woman is a terrible thing. In contrast, sexual assaults of men (which occur most commonly in prison-and which occur more frequently in prison for men than women ${ }^{16}$ ) is fodder for comedians ${ }^{17}$ and those en-

that violence against women was its target. See United States v. Morrison, 529 U.S. 598, 628-633 (2000) (Souter, J., dissenting).

11 Jennifer L. Truman \& Michael Planty, U.S. DeP'T of Justice, Bureau of Justice Statistics, CRIMinAl VictimizATION, $2011 \quad 5$ tbl. 5 (2012), http://bjs.ojp.usdoj.gov/content/pub/pdf/cv11.pdf; U.S. DEP'T OF JUSTICE, BUREAU OF JUSTICE StATISTICS, CRiminal VictimizATION IN THE UNited STATES, 2008 StATISTICAL TABLES, 48 tbl. 35 (2011), http://www.bjs.gov/content/pub/pdf/cvus08.pdf.

12 U.S. DeP'T OF JUSTICE, Crime in the United States 2011, Expanded Homicide Data tbl. 2, http:/www.fbi.gov/about-us/cjis/ucr/crime-in-the-u.s/2011/crime-in-the-u.s.-

2011/tables/expanded-homicide-data-table-2 (last visited Feb. 24, 2013).

13 Margaret Urban Walker, Gender and Violence in Focus: A Background for Gender Justice in Reparations, in THE GENDER of REPARATIONS: UnSETTLING SEXUAL HierARCHIES While Redressing Human Rights Violations 18, 24 (Ruth Rubio-Marin ed., 2009) (claiming that violence against women is "normative").

14 Richard B. Felson \& Scott L. Feld, When a Man Hits a Woman: Moral Evaluations and Reporting Violence to the Police, 35 AgGRESsIVE BEHAV. 477, 483 (2009). See generally Richard B. Felson, The Normative Protection of Women from Violence, 15 Soc. ForUM 91 (2000); RichaRd B. FELSON, Violence AND GENDER REEXAMINED 31-50 (2002).

15 N.W. Pino \& R.F. Meier, Gender Differences in Rape Reporting, 40 SEX RoLES 979, 986 (1999). See also Rachel Kimerling, Gender Differences in Victim and Crime Characteristics of Sexual Assaults, 17 J. InTERPersonal Violence 526, 530 (2002); Patricia Tjaden \& Nancy Thoennes, Prevalence and Consequences of Male-to-Female and Female-to-Male Intimate Partner Violence as Measured by the National Violence Against Women Survey, 6 VIOLENCE AGAINST WOMEN 142, 155 (2000).

16 Cindy Struckman-Johnson et al., Sexual Coercion Reported by Men and Women in Prison, 33 J. SEX RES. 67, 74 (1996) (finding an incidence rate of sexual coercion in male prisoners of $22 \%$, compared with $7 \%$ for women); Cindy Struckman-Johnson \& David StruckmanJohnson, A Comparison of Sexual Coercion Experiences Reported by Men and Women in Prison, 21 J. INTERPERSONAL VIOLENCE 1591, 1605 (2006) (finding that among victims of prison sexual assault, $54 \%$ of men and $28 \%$ of women reported an incident that qualified as rape).

17 See Crackle, Comedians in Cars Getting Coffee - Just a Lazy Shiftless Bastard, YOUTUBE (Aug. 15, 2012), http://www.youtube.com/watch?feature=player_embedded\&v=s1u7A3sEnPY\#! (starting at 5:20); Real Time with Bill Maher: Episode 247 (HBO television broadcast May 4, 2012), available at http://www.hbo.com/real-time-with-bill-maher/episodes/0/247episode/article/new-rules.html. See also Jessica A. Turchik \& Katie M. Edwards, Myths About Male Rape: A Literature Review, 13 PSYCHOL. OF MEN \& MASCULINITY 211, 216 (2012) (noting that "[f]rom movies to TV series such as Family Guy and Son of the Beach to late night show 
gaged in political vituperation ${ }^{18}$ in a way that would be beyond the pale for female victims.

Not only are men disproportionately the victims of criminal activity, they are also disproportionately the subjects of the criminal-justice system. In 2011, 93\% of all prisoners in the United States were male. Although we often hear of the racial disparity in the prison population, the rate of imprisonment of blacks to whites is 6 -to- $1,{ }^{20}$ which is less than half the disparity between the sexes.

We also hear much about "racial profiling" in traffic stops, but little attention is paid to "gender profiling." Yet, males are subject to traffic stops more frequently than females, ${ }^{21}$ are more likely to be cited if stopped, are more likely to be arrested pursuant to the stop, and are more likely to have force used against them. ${ }^{23}$ Despite the fact that in many studies the sex disparity in negative attention from the police is greater than the racial disparity, few seem to view that as a problem. For example, when a Massachusetts study of racial and gender profiling found that, contrary to the authors' expectations, women were substantially less likely to be stopped or cited than men, the au-

hosts and comedians, male rape has been made light of, promoting the myth that it is not a serious issue and likely discourages reporting from victims").

18 For an example, Google "Karl Rove" and "cellmate."

19 E. Ann CARson \& William J. SABol, U.S. DeP’T of Justice, Bureau of Justice STATISTICS, PRISONERS IN 20112 (2012), http://bjs.ojp.usdoj.gov/content/pub/pdf/p11.pdf.

20 Id. at 7.

21 See, e.g., Amy Farrell et al., Rhode Island Traffic Stop Statistics Act: Final Report (2003), Inst. ON RACE AND Just. Publications, at 15, 196 [hereinafter Rhode Island Traffic Stop], http://iris.lib.neu.edu/cgi/viewcontent.cgi? article=1013\&context=race_justice_pubs (last visited Feb. 13, 2013) (finding that more than twice as many males as females were stopped); Amy Farrell et al., Massachusetts Racial and Gender Profiling Study: Final Report (2004), INST. ON RACE And Just. Publications, at 24 [hereinafter Massachusetts Racial and Gender Profiling], http://iris.lib.neu.edu/cgi/viewcontent.cgi?article=1000\&context=race_justice_pubs (last visited Feb. 13, 2013) (finding that across virtually all Massachusetts communities "males were uniformly more likely to be ... cited than women"). But see Garrick Blalock et al., Gender Bias in Power Relationships: Evidence from Police Traffic Stops, 43 APPLIED ECON. 4469, 4471, 4475 (2011) (finding mixed results, but finding that in jurisdictions where police apparently exercised more discretion in giving tickets to stopped motorists-i.e., where a lower percentage of tickets was given to stopped motorists-women received fewer tickets).

22 See Rhode Island Traffic Stop, supra note 21, at 194-95 (statewide, males who were stopped were two-and-a-half times as likely as females to be searched, a disparity greater than the racial disparity in searches). See also Michael R. Smith et al., Differential Suspicion: Theory Specification and Gender Effects in the Traffic Stop Context, 23 JusTICE Q. 271, 287 (2006) (finding that men were more likely than women to be arrested in a traffic stop).

23 Robin S. Engel \& Jennifer M. Calnon, Examining the Influence of Drivers' Characteristics During Traffic Stops With Police: Results from a National Survey, 21 JusTiCE Q. 49, 72-73 (2004) (males are more likely to be stopped, cited, arrested, and to have force used against them, with the latter three effects larger than race effects).

24 Richard J. Lundman \& Robert L. Kaufman, Driving While Black: Effects of Race, Ethnicity, and Gender on Citizen Self-Reports of Traffic Stops and Police Actions, 41 CRIMINOLOGY 195, 204-05 (2003) (sex disparity in traffic stops is larger than any of the racial effects found). 
thors did not then express concern that maybe there was gender profiling against men; instead, they emphasized the need for further information on "the traffic stop behavior of individual officers . . to determine if some officers are stopping [a] larger number of female drivers compared to their similarly situated peers." ${ }^{25}$ The fact that all officers, as a whole, were stopping a larger number of male drivers was simply not on the authors' radar as a problem.

Outside the traffic arena, men fare no better. They are more likely to be suspected of even nonviolent crime. ${ }^{26}$ If charged with a crime, they are less likely than women to have their initial charges reduced through plea bargaining or otherwise. ${ }^{27}$ If convicted of a crime, they are more likely to be sentenced to imprisonment, and, if they are sentenced to prison, they are likely to receive longer sentences. ${ }^{28}$

When it comes to the harshest sentence-the death penalty-the sex difference is stark, indeed. Between 1976 (when the Supreme Court gave the green light to the death penalty) ${ }^{29}$ and January 16, 2013, a total of 1,321 prisoners were executed. ${ }^{30}$ Of those, twelve were women. $^{31}$ Although concern has been raised about racial disparities among defendants sentenced to death, evidence on that score is fairly weak, far weaker than sex disparities in death sentences about which

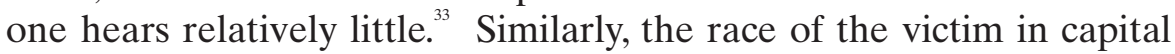

25 Massachusetts Racial and Gender Profiling, supra note 21, at 32.

26 Dean A. Dabney et al., Unexpected Results From an Observational Study of Shoplifting: The Impact of Implicit Stereotyping on Offender Profiling, 33 CRIM. JUST. \& BEHAV. 646, 662-63 (2006). See also Smith et al., supra note 22, at 287-88.

27 Lauren O. Shermer \& Brian D. Johnson, Criminal Prosecutions: Examining Prosecutorial Discretion and Charge Reductions in U.S. Federal District Courts, 27 JusTICE Q. 394, 421 (2010).

28 Fernando Rodriguez et al., Gender Differences in Criminal Sentencing: Do Effects Vary Across Violent, Property, and Drug Offenses?, 87 SoC. SCI. Q. 319, 328, 333 (2006) (also finding that the sex effect was much stronger than the race effect). See also Randa Embry \& Phillip M. Lyons, Jr., Sex-Based Sentencing: Sentencing Discrepancies Between Male and Female Sex Offenders, 7 FEMINIST CRIMINOLOGY 146, 158 (2012) (finding, contrary to the authors' hypothesis, that female sex offenders receive shorter sentences than male offenders).

29 See Gregg v. Georgia, 428 U.S. 153, 187 (1976).

30 U.S. Executions Since 1976, THE Clark COUnTy Prosecuting ATtorney, http://www.clarkprosecutor.org/html/death/usexecute.htm (last visited Feb. 23, 2013).

31 For a slide show of the twelve women executed, see the first twelve photos beginning at, Women Executed in America, CRIME LIBRARY: CRIMINAL MINDS AND METHODS, http://www.trutv.com/library/crime/photogallery/women-executed-in-america.html?curPhoto=1 (last visited Feb. 23, 2013).

32 David C. Baldus \& George Woodworth, Race Discrimination and the Death Penalty, in AMERICA'S EXPERIMENT WITH CAPITAL PUNISHMENT: REFLECTIONS ON THE PAST, PRESENT, AND Future of the Ultimate Penal SANCTION 501, 518-19 (James R. Acker, Robert M. Bohm \& Charles S. Lanier eds., 2d ed. 2003).

33 For an exception, see Victor L. Streib, Rare and Inconsistent: The Death Penalty for Women, 33 FORDHAM URB. L.J. 609, 623-25 (2006). 
cases has been a subject of concern, with the argument being that if the victim is white, the death penalty is more likely to be imposed. However, considerably less attention has been paid to the fact that a defendant convicted of killing a woman is much more likely to be sentenced to death than a defendant convicted of killing a man. A recent study found that California defendants convicted in single-victim murder cases were seven times as likely to be sentenced to death if their victim was a woman than if the victim was a man. ${ }^{35}$ Again, this is a larger disparity than exists in cases finding that race of the victim matters in sentencing.

\section{Domestic Relations}

Another arena in which men seem to be at a disadvantage is in domestic relations and family law. There is a widespread view among many fathers ${ }^{36}$ and attorneys who represent them, ${ }^{37}$ for example, that the "deck is stacked against them" when it comes to seeking child custody. ${ }^{38}$ Statistics in this area are hard to come by and harder to interpret. It is certainly true that in the overwhelming number of cases, it is the mother who retains custody of the children after divorce. ${ }^{39}$ It is very difficult to say to what extent that fact is a consequence of fathers' choice not to seek custody, appropriate determinations by a court, inappropriate determinations by a court, or advice by attorneys to fathers telling them not to bother spending their life savings attempting to obtain custody given the stacked deck.

Disparities between the sexes also exist in the area of domestic violence. One study found, for example, that judges were about thirteen times as likely to grant a temporary restraining order requested by a female plaintiff as one requested by a male plaintiff (and sixteen

\footnotetext{
34 See Baldus \& Woodworth, supra note 32.

35 Steven F. Shatz \& Naomi R. Shatz, Chivalry Is Not Dead: Murder, Gender, and the Death Penalty, 27 BERKELEY J. GENDER L. \& JUST. 64, 107 (2012).

36 See AM. COALITION FOR FATHERS \& CHILD., www.acfc.org (last visited Apr. 19, 2013).

37 See David T. Pisarra, The "Y" Factor: Gender Bias, Child Custody and the Great Parenting Myth, HufFington POsT (Mar. 28, 2011), http://www.huffingtonpost.com/david-tpisarra/the-y-factor-gender-bias-_b_838631.html (family law attorney); Joseph E. Cordell, Is the Playing Field Level For Men In the Family Court System?, HuFFInGTON POST (July 27, 2011), http://www.huffingtonpost.com/joseph-e-cordell/is-the-playing-field-leve_b_909285.html (family law attorney).

38 See generally STEPHEN BASKerville, TAKen InTO CUSTODY: ThE WAR Against FATHERS, MARRIAGE, AND THE FAMILY (2007).

39 Timothy S. Grall, U.S. Census Bureau, Custodial Mothers and Fathers and THEIR CHILD SUPPORT: 20091 (2011), http://www.census.gov/prod/2011pubs/p60-240.pdf (17.8\% of custodial parents are fathers).
} 
times as likely when the level of violence was controlled for). ${ }^{40}$ Another study found that male requests for Abuse Protective Orders were over nine times as likely to be denied as female requests, despite the fact that the abuse alleged by male and female victims was roughly equal.

When women's advocates complained that police were not taking complaints of domestic violence seriously, legislators responded with mandatory arrest laws, requiring police to arrest suspected offenders. ${ }^{42}$ Consequently, more people were arrested, but the rate of female arrests increased even more than that of male arrests, because when there were signs of mutual aggression, police would often arrest both members of the couple. The response to the increase in female arrests was "predominant aggressor" laws, which require police to determine who the "predominant" or "dominant" aggressor was." As the California statute makes clear, however, "dominant aggressor" does not mean "initial aggressor." aggressor by a number of criteria, including relative size, which, of course, tends to result in proportionately greater arrests of men.

Perhaps not surprisingly, domestic-violence advocates viewed the increase in female arrests as a consequence of mandatory arrest laws as a bad thing. One study asked, for example, "Why, then, has a potential positive change (greater enforcement of domestic violence laws) resulted in such a potential negative outcome (more arrests of women)?" Specifically, the complaint was that the female share of those arrested for felony domestic violence in California increased from $5 \%$ to $18 \%$ between 1987 and 2000 . However, this should be a "negative" outcome only if $5 \%$ is (or is closer to) the right number of female arrests, while $18 \%$ is too many. But why should one suppose that when men are arrested at four-and-a-half times the rate of

40 Henry J. Muller et al., Do Judicial Responses to Restraining Order Requests Discriminate Against Male Victims of Domestic Violence?, 24 J. FAM. VIOLENCE 625, 631 (2009).

41 Steve Basile, Measure of Court Response to Requests for Protection, 20 J. FAM. VIOLENCE 171, 172, 175 (2005).

42 See generally John Hamel, In Dubious Battle: The Politics of Mandatory Arrest and Dominant Aggressor Laws, 2 PARTNER ABUSE 224 (2011).

43 William DeLeon-Granados et al., Arresting Developments: Trends in Female Arrests for Domestic Violence and Proposed Explanations, 12 Violence AGAINST WOMEN 355, 359, 364-66 (2006).

44 See Cal. Penal Code $\S 13701$ (2013) (providing that law enforcement agencies should develop policies that discourage dual arrests and that they attempt to identify the "dominant aggressor," who is "the person determined to be the most significant, rather than the first, aggressor").

45 Hamel, supra note 42, at 227.

46 DeLeon-Granados, supra note 43, at 366. 
women it is women who are being disadvantaged? The answer has to be that women almost never commit domestic violence.

The caricature in much of the domestic violence literature would certainly support the notion that $18 \%$ of those arrested being female is too many. ${ }^{47}$ Women, it is urged, seldom engage in physical aggression against their partners, and when they do they are acting defensively and do not cause much harm. ${ }^{48}$ The data do not support that caricature, however. $^{49}$ A large-scale meta-analysis of studies on partner violence found that across studies men were slightly more likely to be recipients of physical aggression from their partners, and women were somewhat more likely than men to suffer injuries, being $62 \%$ of those suffering visible injuries and $65 \%$ of those requiring medical care. ${ }^{50}$ From those data, it is hard to say that too many women are being arrested.

\section{Education}

From the very early stages of education, girls do better than boys. In primary and secondary schools, girls outperform boys in reading at all levels measured by the NAEP (grades 4, 8, and 12). ${ }^{51}$ Although boys slightly outperform girls in math in grades 8 and 12, the margin is much smaller than the female advantage in reading. ${ }^{52}$ Boys are twice as likely as girls to be suspended from school, and three times as likely to be expelled. ${ }^{53}$ Girls are held back a grade less often than boys, and are less likely to drop out of high school. ${ }^{54}$ Boys are much more likely to be diagnosed with $\mathrm{ADHD}^{55}$ and to be placed in special education. One reason that boys do less well in school is that schools tend to re-

47 See generally Donald G. Dutton \& Tonia L. Nicholls, The Gender Paradigm in Domestic Violence Research and Theory: Part 1-The Conflict of Theory and Data, 10 AGgRESSION \& VIOLENT BEHAV. 680 (2005).

48 Id. at 705.

49 See generally id.

50 John Archer, Sex Differences in Aggression Between Heterosexual Partners: A MetaAnalytic Review, 126 PSYCHOL. BULL. 651, 664-65 (2000).

51 Thomas D. SNyder \& SAlly A. Dillow, NAT'L CTR. For Educ. STATISTICS, Digest OF Educ. Statistics 2011, 193 tbl.125 (2012) [hereinafter Digest of Education Statistics], http://nces.ed.gov/pubs2012/2012001.pdf.

52 Id. at 202 tbl. 134, 209 tbl. 141.

53 Id. at 246-47 tbl. 170.

54 Id.

55 LARA J. AKInBAMi ET AL., NAT'L CTR. FOR HEAlth STATISTICS, ATTENTION DEFICIT HyPeractivity DisORder AMONG ChILdREN AgED 5-17 YeARS IN THE UNITED STATES, 1998-2009 1-2 (2011), http://www.cdc.gov/nchs/data/databriefs/db70.pdf.

56 Martha J. Coutinho \& Donald P. Oswald, State Variation in Gender Disproportionality in Special Education: Findings and Recommendations, 26 REMEDIAL \& SPECIAL EDUC. 7, 7 (2005). 
ward feminine behaviors and punish masculine behaviors (in both sexes).

After high school, females do better than males at each level. They receive $57 \%$ of bachelor's degrees (and have received a majority of them since 1982), $60 \%$ of master's degrees, and $52 \%$ of doctorates. Despite females' seeming advantages in universities, concern is more often expressed about the plight of university women than of university men. My university, like countless others, has a "Commission on the Status of Women," "59 but no corresponding commission for men. So, what is the basis for the concern about the females in education? Almost exclusively, it is the relatively small number of women getting advanced degrees in STEM (Science, Technology, Engineering and Mathematics) fields. Why is this a problem? Because it reflects a "gap," and it is one that is viewed as disfavoring women.

\section{E. The Workplace}

Having said a lot about non-workplace-related phenomena, I will mention just a few things having specifically to do with the workplace. When people complain of "gaps" in the workplace, they typically are referring to one or more of the following: the "gender gap in compensation," the "glass ceiling," or occupational segregation.

It is certainly true that full-time male employees earn more than full-time female employees. In 2011, the female-to-male weekly earnings ratio was $.82 .{ }^{62}$ But it is also true that there is a "gender gap" in

57 Warren Farrell has observed: "[F]rom a boy's perspective, school itself is filled with women. It is women teaching him how to be a boy by conforming to what women tell him to do after he's been trained to conform to what his mother tells him to do. On the one hand, history books show him that his role is to be a hero who takes risks and, on the other, his female teacher is telling him not to take risks- to not roughhouse, not shout out an answer spontaneously, not use swear words, not refer to sex, not get his hair mussed, his clothes dirty." WARREN FARRELL, The Myth of Male Power: Why Men Are the Disposable SeX 15 (1993). See also Peter J. Burke, Gender Identity, Sex, and School Performance, 52 SoC. PSYCHOL. Q. 159, 165 (1989) (finding that, among 6th through 8th graders, the more feminine the gender identity of both boys and girls, the higher their grades in all subjects, irrespective of the sex of the teacher).

58 Digest of Education Statistics, supra note 51, at 288 tbl. 196. Since 2005-06, more females than males have been awarded doctorates. Id. at 281.

59 See The President's Commission on the Status of Women, WAYNE STATE UNIVERSITY, http://cosw.wayne.edu/.

60 See text accompanying notes 74-83, infra. See generally Kingsley R. Browne, Women in Science: Biological Factors Should Not Be Ignored, 11 CARDOZO WOMEN's L.J. 509 (2005).

61 See generally Kingsley R. Browne, Sex and Temperament in Modern Society: A Darwinian View of the Glass Ceiling and the Gender Gap, 37 ARIZ. L. REV. 971 (1995) [Sex and Temperament]; Kingsley R. BROWNE, BIOLOGY AT WORK: RETHINKING SEXUAL EQUALITY 35-49 (2002) [hereinafter BIOLOGY AT WORK].

62 U.S. DEP'T OF LABOR, BUREAU OF LABOR STATISTICS, WOMEN IN THE LABOR FORCE: A DATАВООK 20122 (2013), http://www.bls.gov/cps/wlf-databook-2012.pdf (last visited Feb. 24, 2013). 
hours worked, as well. In 2011, full-time male employees worked approximately $14 \%$ more hours than full-time female employees (40.6 hours compared to 35.6 hours)..$^{63}$ At the high end of hours, the disparity is even greater. One study found, for example, that professionalmanagerial men are 2.7 times as likely as their female equivalents to work fifty or more hours per week. ${ }^{64}$ Moreover, there is also a "gender gap" in occupational deaths. Because men tend to work more dangerous jobs than women, approximately $92 \%$ to $93 \%$ of workplace fatalities each year are men. ${ }^{65}$ Men also place greater value on high earnings $^{66}$ and select more competitive fields of employment. ${ }^{67}$

It is also true that men hold a disproportionate number of top executive positions. ${ }^{68}$ In 2012, women constituted $14.3 \%$ of Fortune 500 executives and $8.1 \%$ of executive top earners. But it is also true that men have a substantially higher preference for "tournament" situations in which there are winners and losers, ${ }^{69}$ such as the "partnership tournament" prevalent in large law firms or the climb up the "greasy pole" of the corporation. ${ }^{70}$ They are also more willing to comply with the expectation of working long hours associated with those tournament competitions. ${ }^{71}$ Men are also more willing to uproot themselves from networks of friends and relatives to move off to a new city, a career move that is a prerequisite to advancement in many organiza-

63 Id. at 77 tbl. 21.

64 See JoAn C. Williams \& HeAther Boushey, The Three FACES OF Work-FAmiLy CONflict: THE POOR, THE Professionals, AND THE Missing Middle 7 (2010), http://www.americanprogress.org/wp-content/uploads/issues/2010/01/pdf/threefaces.pdf.

65 U.S. DEP'T OF LABOR, BUREAU OF LABOR STATISTICS, FATAL OCCUPATIONAL INJURIES BY SELECTED CHARACTERISTICS, 2003-2011 3, http://www.bls.gov/iif/oshwc/ cfoi/all_worker.pdf.

66 Satoshi Kanazawa, Is "Discrimination" Necessary to Explain the Sex Gap in Earnings?, 26 J. ECON. PSYCHOL. 269, 276-77 (2005); Terence Martin \& Bruce Kirkcaldy, Gender Differences on the EPQ-R and Attitudes to Work, 24 PERSONALITY \& INDIVIDUAL DIFFERENCES 1, 4 (1998).

67 See Judith A. McDonald \& Robert J. Thornton, Do New Male and Female College Graduates Receive Unequal Pay?, 42 J. HUM. RESOURCES 32, 44 (2007) (finding that approximately $95 \%$ of the sex difference in starting salaries of new college graduates is accounted for by college major).

68 The 2012 Catalyst Census: Fortune 500 Women Executive Officers and Top Earners, CATALYST (Dec. 11, 2012), http://www.catalyst.org/knowledge/2012-catalyst-census-fortune-500women-executive-officers-and-top-earners.

69 Muriel Niederle \& Lise Vesterlund, Gender Differences in Competition, 24 NEGOtiation J. 447, 450 (2008).

70 See generally MARC GALANTER \& THOMAS PALAY, TOURNAMENT OF LAWYERS: THE TRANSFORMATION OF THE BIG LAW FIRM (1991).

71 Olivia A. O'Neill \& Charles A. O'Reilly, Careers as Tournaments: The Impact of Sex and Gendered Organizational Culture Preferences on MBAs' Income Attainment, $31 \mathrm{~J}$. ORGANIZATIONAL BEHAV. 856, 868-69 (2010). 
tions. ${ }^{72}$ Executives of both sexes tend to be competitive, assertive, ambitious, strongly career-oriented risk-takers, ${ }^{73}$ but that profile is more typical of men than of women.

Finally, it is true that there remains a fair amount of occupational segregation, with men and women often working in different jobs. ${ }^{75}$ Over $90 \%$ of receptionists $(91.0 \%)$, dietitians and nutritionists $(92.8 \%)$, registered nurses $(90.3 \%)$, and pre-school and kindergarten teachers $(97.8 \%)$ are female, for example, and over $90 \%$ of electrical and electronics (90.8\%) and mechanical (94.8\%) engineers, firefighters $(96.2 \%)$, mechanics $(98.8 \%)$, and pest exterminators $(98.3 \%)$ are male. ${ }^{76}$ Some scientific fields, such as mathematics $(70.1 \%)$, physics $(72.7 \%)$, and engineering $(77 \%)$, continue to graduate a disproportionate number of male Ph.D.s. ${ }^{77}$ But it is also true that women have achieved parity or are even on their way to "taking over" other fieldssuch as biology (53\%), pharmacy (63.8\%), psychology $(73.3 \%){ }^{70}{ }^{80}$ and veterinary medicine $(77.6 \%){ }^{81}$ High-status professions such as law $(47.2 \%)^{82}$ and medicine $(48.2 \%)^{83}$ are reaching parity among new entrants. Similarly, women obtain the greater share of Ph.D. degrees in fields such as anthropology $(59.0 \%)^{84}$ and sociology $(62.0 \%)$.

Only some statistical disparities in the workplace seem to be the subject of much concern, however. For example, although the proportion of men becoming veterinarians is about the same as the proportion of women becoming Ph.D. engineers, and the proportion of men becoming Ph.D. psychologists is smaller than the proportion of women earning Ph.D.s in mathematics and statistics, it is only women's under-representation that elicits concern. The low proportion of women in STEM fields is viewed as a problem, but the high propor-

72 David C. Baldridge et al., Saying "No" to Being Uprooted: The Impact of Family and Gender on Willingness to Relocate, 79 J. OCCUPATIONAL \& ORGANIZATIONAL PSYCHOL. 131, 142-45 (2006).

73 Kenneth R. MacCrimmon \& Donald A. Wehrung, Characteristics of Risk Taking Executives, 36 MGMT. SCI. 422, 423-25 (1990).

74 See Biology AT Work, supra note 61, at 13-24.

75 See generally Kingsley R. Browne, Evolved Sex Differences and Occupational Segregation, 27 J. ORGANIZATIONAL BEHAV. 143 (2006).

76 U.S. DEP'T of LABOR, BurEaU OF LABOR STATistics, Highlights OF WOMEN'S EARNINGS IN 201110 tbl. 2 (2012), http://www.bls.gov/cps/cpswom2011.pdf.

77 Digest of Education Statistics, supra note 51, at 426, 431, 432 tbl. 290.

78 Id. at 422.

$79 \quad I d$. at 429.

$80 \quad I d$. at 432

81 Id. at 429.

$82 \quad I d$. at 431.

83 Id. at 429.

84 Id. at 433 .

85 Id. 
tion in psychology, pharmacy, veterinary medicine, sociology, and anthropology is not. It seems that to many "advocates" for women, the only acceptable situation is that women either achieve parity or domination in every field. ${ }^{86}$ However, as long as there are roughly equal numbers of men and women in the workplace, that is no more realistic a possibility than that all of the children in Lake Woebegone can be "above average."

One also assumes that if women were eleven times as likely to die on the job, the "gender gap in workplace deaths" would be the topic of policy discussion, legislative initiatives, and, no doubt, numerous lawschool symposia. Yet one seldom hears about a "gender gap in occupational deaths," despite the fact that eleven men die on the job for every woman who dies. When viewed through the current lens of "gender equality," the former is a "problem" while the latter is merely a "fact."

\section{WHAT IS THE CAUSE OF THE VARIOUS GENDER GAPS?}

I would suggest that some of the previously described "gaps" that work to the detriment of males-the life-expectancy gap, the crime gap, the parental-custody gap, the gap in primary and secondary educationare not unrelated to the workplace "gaps," and that many of the relative advantages and disadvantages enjoyed by each sex is a reflection of tradeoffs. ${ }^{88}$ What is it that causes one to earn more money and to rise higher in organizations? Among other causes are competitiveness,

86 See generally Browne, supra note 60. This one-sided approach to "equality" seems to be a product of what philosopher David Benatar has called "partisan feminists"-whose concern is limited to advancing the interests of females-as opposed to "egalitarian feminists"-whose fundamental concern is equality between the sexes. DAVID BENATAR, THE SECOND SEXISM: DisCRIMINATION AGAinst MEN AND Boys 14 (2012).

87 One vivid illustration of the different treatment given to statistical disparities is a Labor Department study reporting that $40 \%$ of women killed at work were murdered compared to only $15 \%$ of men. See High Murder Rate for Women on Job, N.Y. TIMES, Oct. 3, 1993, at 29. Labor Department officials interpreted this statistic to be a troubling indicator that "women are more likely to be murdered on the job than men." See Nussbaum Says Employers Often Deny, Ignore Women's Workplace Health, Safety Concerns, Daily Lab. Rep. (BNA) No. 219, at D-7 (Nov. 16, 1993). Secretary of Labor Robert Reich attributed the high rate of female murders to the number of women working at convenience stores at night. High Murder Rate for Women on Job, supra note 87. This was all nonsense, of course. Far more men than women are murdered in the workplace. The report itself indicated that men accounted for $93 \%$ of all job-related deaths but only $55 \%$ of the work force. Thus, less than $3 \%(40 \%$ of $7 \%)$ of workplace deaths were murders of women, while almost $14 \%$ (15\% of $93 \%)$ were murders of men. Thus, a man was almost four times as likely to be murdered in the workplace as a woman (and approximately eleven times as likely to be killed on the job by all causes combined). The reason for the high "murder rate" was not that women were murdered at a higher rate than men; it is that women were killed by other causes at a much lower rate. That's too much of a dog-bites-man story to be interesting, though.

88 See Roy F. BAumeister, Is There ANYTHING GoOd AbOUT MEn? 38-40 (2010). 
desire for dominance and status (including specifically the desire to earn more money), willingness to take risks (both physical and nonphysical), and willingness to sacrifice family time for a career, for example, by working more hours. ${ }^{89}$ There is a robust literature showing that the above traits are not randomly distributed with respect to sex..$^{90}$

The traits that lead to workplace rewards are two-edged swords, however. Even in the workplace, it is in the nature of risk-taking that outcomes may be either good or bad; if they were only good, we would not call it "risk." So, although it is true that there are more spectacular male successes there are also more spectacular failures, though they get far less attention. Similarly, the tendency of men more than women to devote themselves single-mindedly to their careers is certainly related to some of the workplace gaps, but it is also the reason why women more often end up with custody of the children upon divorce when status as primary caretaker is given weight in custody decisions. That same devotion to the job can also lead to premature death from overwork. ${ }^{91}$ Moreover, many of the traits that may pay off in the workplace are the same traits that can lead to violent crime and early death. ${ }^{92}$

The fact is that the workplace requires tradeoffs, and those tradeoffs are likely to be weighed differently by different people, according to their own preferences and motivations. What leads one person to choose a career in finance and another person to choose a career in elementary education? ${ }^{93}$ Or one person to be a high-rise iron worker and another a dental hygienist? Or one person to intensify workforce commitment after becoming a parent and another person to reduce it? Individual differences in talents no doubt play a large role, as do well-established sex differences in social preferences, risk preferences, and competitive preferences. ${ }^{94}$ Which is the "better" choice? It depends upon the abilities and preferences of the individuals, but more men will choose careers in finance and as iron-workers, and more

89 BIOLOGY AT WORK, supra note 61, at 35-49.

90 Id. at $13-24$

91 Melanie Haiken, Is Stress from Overwork Wrecking Your Heart?, Forbes.COM (Aug. 23, 2011), http://www.forbes.com/sites/melaniehaiken/2011/08/23/is-stress-from-overwork-wreckingyour-heart.

92 Margo Wilson \& Martin Daly, Competitiveness, Risk Taking, and Violence: The Young Male Syndrome, 6 ETHology \& Sociobiology 59, 63-65 (1985) (finding that "trivial altercations" resulting from male status competition were a frequent cause of homicides).

93 Despite the fact that women obtain $60 \%$ of master's degrees nationwide, they receive only about one-third of the master's degrees in finance but almost 9 out of 10 of those in elementary education. Digest of Education Statistics, supra note 51, at 421 tbl. 290, 423 tbl. 290, 425 tbl. 290.

94 See generally Rachel Croson \& Uri Gneezy, Gender Differences in Preferences, 47 J. ECON. LITERATURE 448 (2009). 
women will choose to be dental hygienists and elementary-school teachers.

Despite the frequent assertion that the gaps that favor men (although not those that favor women) are results of invidious social forces, the truth seems to be somewhat more basic. If the various workplace and non-workplace gaps could be distilled down to a single word, that word would not be "discrimination" but "testosterone." Testosterone is associated with a variety of sex-typed behaviors and traits (even in females), including dominance seeking, aggression, ${ }^{98}$ risk preferences, ${ }^{99}$ fear, ${ }^{100}$ spatial ability, ${ }^{101}$ occupational preferences, ${ }^{102}$ entrepreneurship, ${ }^{103}$ nurturance, ${ }^{104}$ and empathy, ${ }^{105}$ and it may also be

95 See Kingsley R. Browne, Biological Sex Differences in the Workplace: Reports of the End of Men Are Greatly Exaggerated (As Are Claims of Women's Continued Inequality), 93 B.U. L. REV. 769 (forthcoming 2013) (manuscript at 780-82) (on file with author).

96 Melissa Hines et al., Testosterone During Pregnancy and Gender Role Behavior of Preschool Children: A Longitudinal, Population Study, 73 CHILD DEV. 1678, 1683 (2002); Annamarja Lamminmäki et al., Testosterone Measured in Infancy Predicts Subsequent Sex-Typed Behavior in Boys and in Girls, 61 HORMONES \& BEHAV. 611, 614 (2012).

97 Christoph Eisenegger et al., The Role of Testosterone in Social Interaction, 15 TRENDS COGNitive SCIENCES 263, 269 (2011); John Archer, Testosterone and Human Aggression: An Evaluation of the Challenge Hypothesis, 30 NeuroscienCE \& BIOBEHAVIORAL ReVIEWs 319, 332-34 (2006).

98 Francis T. McAndrew, The Interacting Roles of Testosterone and Challenges to Status in Human Male Aggression, 14 AgGression \& Violent BeHAV. 330, 331 (2009); Vickie Pasterski et al., Increased Aggression and Activity Level in 3- to 11-Year-Old Girls with Congenital Adrenal Hyperplasia (CAH), 52 HORMONES \& BEHAV. 368, 371-72 (2007); Archer, supra note 97, at 33234.

99 Eric Stenstrom et al., Testosterone and Domain-Specific Risk: Digit Ratios (2D:4D and rel2) as Predictors of Recreational, Financial, and Social Risk-Taking Behaviors, 51 PERSONALITY \& INDIVIDUAL DIFFERENCES 412, 414 (2011); Richard Ronay \& William von Hippel, The Presence of an Attractive Woman Elevates Testosterone and Physical Risk Taking in Young Men, 1 Soc. PsyCHOL. \& PeRsonality SCI. 57, 61 (2010).

100 Jack van Honk et al., Testosterone Reduces Unconscious Fear but Not Consciously Experienced Anxiety: Implications for the Disorders of Fear and Anxiety, 58 BIOLOGICAL PSYCHIATRY 218, 222-23 (2005).

101 David A. Puts et al., Spatial Ability and Prenatal Androgens: Meta-Analyses of CAH and Digit Ratio (2D:4D) Studies, 37 Archives SeXuAl BeHAV. 100, 109 (2008); Gina M. Grimshaw et al., Mental Rotation at 7 Years: Relations with Prenatal Testosterone Levels and Spatial Play Experiences, 29 BRAIN \& COGNITION 85, 95 (1995).

102 Paola Sapienza et al., Gender Differences in Financial Risk Aversion and Career Choices Are Affected by Testosterone, 106 PROCEEDINGS NAT'L ACAD. SCI. 15268, 15270 (2009); Sheri A. Berenbaum, Effects of Early Androgens on Sex-Typed Activities and Interests in Adolescents with Congenital Adrenal Hyperplasia, 35 HORMONES \& BEHAV. 102, 106 tbl. 2, 107 (1999).

103 Roderick E. White et al., Entrepreneurs and Evolutionary Biology: The Relationship Between Testosterone and New Venture Creation, 100 OrganizATIONAL BEHAV. \& HuMAN DECISION PROCESS 21, 30 (2006).

104 Elizabeth Hampson, On the Relation Between 2D:4D and Sex-Dimorphic Personality Traits, 37 ARCHIVES SEXUAL BEHAV. 133, 139 (2008).

105 Jack van Honk et al., Testosterone Administration Impairs Cognitive Empathy in Women Depending on Second-to-Fourth Digit Ratio, 108 ProceEdings NAT. ACAD. SCI. 3448, 3450 
causally related to differences in life expectancy. ${ }^{106}$ These traits are all related in one way or another to most of the gaps that have been discussed.

The failure to acknowledge tradeoffs has resulted in a somewhat distorted perspective on the part of some advocates for women. They seem to want all of the benefits of being a man with none of the costs. The question should not be "do you want the good stuff or the bad stuff?"; it should instead be "do you want the high-testosterone package or the low-testosterone package, each of which comes with some good and some bad?"107

\section{CONCLUSION}

Statistical disparities, so-called "gaps," do not necessarily demonstrate discrimination, and they do not necessarily require correction. My purpose in describing sex differences in outcomes in the area of health and longevity, criminal victimization and punishment, domestic relations, and education is not to argue that these disparities necessarily reflect discrimination, although some may. ${ }^{108}$ Instead, it is to show that there is a broad range of gaps that favor females, but the singleminded focus on "female disadvantage" obscures a more complicated reality.

Individual differences in motivations and preferences cause different individuals to engage in different behaviors, including choices of career paths. Sex differences in motivations and preferences cause

(2011); Erno Jan Hermans et al., Testosterone Administration Reduces Empathetic Behavior: A Facial Mimicry Study, 31 Psychoneuroendocrinology 859, 863 (2006).

106 Kyung-Jin Min, The Lifespan of Korean Eunuchs, 22 CURRENT BIOLOGY R792, R793 (2012) (finding that Korean eunuchs lived fifteen to nineteen years longer than non-castrated men of similar social status).

107 The focus on testosterone should not be taken to imply that only testosterone is important to the differences at hand, as estrogens and progesterone also play a role. For example, estrogen appears to exert a depressing effect on spatial ability, such that in low-estrogen phases of the menstrual cycle, women's performance on spatial tests increases. See Catherine Gouchie \& Doreen Kimura, The Relationship Between Testosterone Levels and Cognitive Ability Patterns, 16 Psychoneuroendocrinology 323, 331 (1991); Cheryl M. McCormick \& Sarah M. Teillon, Menstrual Cycle Variation in Spatial Ability: Relation to Salivary Cortisol Levels, 39 HORMONES \& BEHAV. 29, 34-35 (2001). Similarly, in low-estrogen (and low-progesterone) phases of the menstrual cycle, women exhibit greater competitiveness. Thomas Buser, The Impact of the Menstrual Cycle and Hormonal Contraceptives on Competitiveness, 83 J. ECON. BEHAV. \& ORG. 1, 5 (2012). On the other hand, during the high-estrogen fertile portion of the cycle, women exhibit lesser risk-taking. Tara J. Chavanne \& Gordon G. Gallup, Jr., Variation in Risk Taking Behavior Among Female College Students as a Function of the Menstrual Cycle, 19 EvOLUTION \& HUMAN BEHAV. 27, 31 (1998); Arndt Bröder \& Natalia Hohmann, Variations in Risk Taking Behavior over the Menstrual Cycle: An Improved Replication, 24 Evolution \& HuMAN BeHAV. 391, 397 (2003).

108 See BENATAR, supra note 86 , at 101-72. 
men and women to choose differently, as well. After the choice is made, however, it makes no more sense to label women as "disadvantaged" simply because they chose a less remunerative path that was attractive in other ways than it does to call law professors "disadvantaged" because they could make more money in private practice. It similarly makes no sense to deny the reality of choice on the ground that women's choices may be constrained. If the existence of constraints converts choice to "choice," then no one chooses; they only "choose," because no one's choices are unconstrained. ${ }^{109}$ The assumption that women's choices should be unconstrained and costless seems to be based on the mistaken belief that men's are. As economist Jennifer Roback observed, "[o]nce we observe that people sacrifice money income for other pleasurable things we can infer next to nothing by comparing the income of one person with another."110

The irony in the complaints of female disadvantage is that they simultaneously denounce the male focus on acquiring resources and measure women's success exclusively by that same measure. Yet women themselves may define their own success not only (or primarily) by money but also by other things, including, significantly, their care for the family. It seems a bit patronizing to argue that they made the "wrong" choice or to pity them for the choice they "had to" make.

Many of the gender gaps described in this article are unlikely to disappear. They are to a large extent a reflection of (dare I say it?) human nature. Specific instances of sex disparities may actually reflect injustice, but the mere fact of disparities does not. Thus, it is injustice that should cry out for "rectification," not disparities.

109 For a discussion of choice versus "choice," see Sex and Temperament, supra note 61, at 1086-87.

110 See Jennifer Roback, Beyond Equality, 82 GEO. L.J. 121, 124 (1993). 